\title{
Nitrogen bound to manure fiber is increased by applications of simple phenolic acids
}

\author{
Jonathan J. Halvorson ${ }^{1 *} \mathbb{D}$, Scott L. Kronberg ${ }^{1}$, Rachael G. Christensen' ${ }^{1}$ Ann E. Hagerman² and David W. Archer ${ }^{1}$
}

\begin{abstract}
Background: Polyphenolic compounds like tannins can increase nitrogen $(\mathrm{N})$ excreted in feces when consumed by ruminants but less often noted is increased $\mathrm{N}$ in fecal acid detergent fiber (ADF-N). Some simple phenolics are thought to facilitate binding interactions between nitrogenous compounds and soil. We hypothesized that contact with common phenolic acids, such as found in crops, could increase ADF-N, in excreted manure.

Methods: We performed two separate experiments to test our hypothesis. In the first experiment, we applied three solutions (i.e., $0.001,0.01,0.1 \mathrm{M}$ ) of sodium benzoate (B0), sodium 4-hydroxybenzoate (B1), 3,4-dihydroxybenzoic acid (B2), gallic acid (B3), ammonium benzoate (AB), and ammonium chloride (AC) to dried pulverized manure and measured ADF-N. In the second experiment we modified the methodology, by applying more compounds at a single concentration $(0.001 \mathrm{M})$ and including an added nitrogen $\left(\mathrm{NH}_{4} \mathrm{Cl}\right)$ treatment.

Results: We found a statistically significant interaction between treatment and concentration in the first experiment $(P<0.0001)$, but the main effects were inconsistent and there was no significant difference between the treatment means and the control mean (samples treated with water). Conversely, we observed a significant treatment effect in the second experiment $(P<0.0001)$, but no significant effect of the added $N$ or interaction. Samples treated with water, $\mathrm{B} 0$, or $\mathrm{B} 3$ were similar and indistinguishable from untreated manure. The treatment with $\mathrm{B} 1$, caffeic acid, (CAF), or B2 increased ADF-N from 13.2 to $17.5 \%$ while $+(-$ )catechin (CAT), and $p$-coumaric acid ( $p$-COUM), increased it by 19.7 and $22.2 \%$ respectively. Epigallocatechin gallate (EGCG) and ferulic acid (FER) increased ADF-N by 32.6 and 34.1\%, respectively.
\end{abstract}

Conclusions: The results support our hypothesis that $\mathrm{N}$ in manure can complex with manure ADF following exposure to benzoic acid and especially cinnamic acid derivatives. This resulted in greater amounts of $\mathrm{N}$ bound to relatively recalcitrant fibers in excreted manure. Thus, $\mathrm{N}$ mineralization may be impacted by increasing or decreasing the amount of $\mathrm{N}$ bound to manure fibers or other recalcitrant soil compounds such as lignin, but it is unclear whether such N would be less available to plants, or for volatilization, or leaching.

Keywords: Manure, Acid detergent fiber, Nitrogen, Phenolic acids, Hydroxybenzoic acids, Hydroxycinnamic acids, Polyphenol

*Correspondence: jonathan.halvorson@usda.gov

1 USDA Agricultural Research Service, Northern Great Plains Research Laboratory, Mandan, ND 58554, USA

Full list of author information is available at the end of the article

\section{Background}

The phenolic class of secondary plant metabolites (PSMs) ranges from large complex tannins to simple phenolic acids. These compounds participate in many important plant functions including responses to herbivory, environmental stress, and competition (e.g., Kong et al. 2019; Kumar et al. 2020; Naikoo et al. 2019; Siqueira et al. 1991; Yang et al. 2018). In soils, PSMs participate in numerous original author(s) and the source, provide a link to the Creative Commons licence, and indicate if changes were made. The images or other third party material in this article are included in the article's Creative Commons licence, unless indicated otherwise in a credit line to the material. If material is not included in the article's Creative Commons licence and your intended use is not permitted by statutory regulation or exceeds the permitted use, you will need to obtain permission directly from the copyright holder. To view a copy of this licence, visit http://creativecommons.org/licenses/by/4.0/. The Creative Commons Public Domain Dedication waiver (http://creativeco mmons.org/publicdomain/zero/1.0/) applies to the data made available in this article, unless otherwise stated in a credit line to the data. 
reactions that affect biological, chemical, and physical phenomena, stimulate or inhibit soil microorganisms, and affect important biogeochemical processes such as organic matter formation and nutrient cycling (e.g., Chomel et al. 2016; Hättenschwiler and Vitousek 2000; Mallik 1997; Mandal et al. 2010; Marchiosi et al. 2020; McGivern et al. 2021; Schmidt et al. 2013; Siqueira et al. 1991). When consumed by ruminants such as cattle or goats, PSMs (especially tannins) can change nutrient use efficiency and can improve animal health and environmental services (e.g., Kelln et al. 2020; Ku-Vera et al. 2020; Maxin et al. 2020).

Large complex PSMs such as tannins are not usually associated with annual crops. Instead, relatively simple phenolic acids such as hydroxybenzoic acids and hydroxycinnamic acids are more common, especially in cereals (Gunia-Krzyżak et al. 2018; Naczk and Shahidi 2006; Otte et al. 2020; Stuper-Szablewska and Perkowski 2019). Simple phenolic compounds may enter soil as decomposition products, root exudates, or through the actions of microorganisms and may participate in important soil processes like nutrient cycling or the formation of protected or polymerized soil organic matter (Šmejkalová et al. 2006; Sokol et al. 2019). Tannins and phenolic acids are known to sorb to soil (Cecchi et al. 2004; Makino et al. 1996) and have been found to reduce $\mathrm{N}$ solubility when added to soil presumably through abiotic mechanisms that bind unspecified forms of $\mathrm{N}$ to soil organic matter or the inorganic soil matrix (Halvorson et al. 2013, 2016). Less often noted are changes in ruminant manure composition associated with consumption of phenolic compounds including increases in the amount of $\mathrm{N}$ recovered in fecal acid detergent fiber (ADF-N) (Halvorson et al. 2017; Powell et al. 2009).

Acid detergent fiber in forages and manure is composed of cellulose, lignin, and acid-insoluble ash (Van Soest et al. 1991). Forage ADF is typically composed of about $80 \%$ cellulose, with lignin ranging from about $11 \%$ in grasses to about $16 \%$ in alfalfa and $0.3-2.9 \%$ ash (Colburn and Evans 1967). Espinosa et al. (2017) reported that cereal straws (e.g., crop residues) are composed of $34-44 \%$ cellulose, $27-38 \%$ hemicellulose, $16-18 \%$ lignin and $6-9.5 \%$ ash. Any $\mathrm{N}$ that is sequestered in these plant cell wall fractions has low biological availability and tends to be recovered in ADF. Such N is a feature of fresh and stockpiled forages and has been attributed to the formation of complexes in the presence of tannins or to Maillard browning reactions caused by heating and drying (Licitra et al. 1996). In manure, lignin may directly or indirectly inhibit the decomposition of cellulose by competing for or releasing phenolic degradation products that inhibit hydrolytic enzyme activity. (Kim 2018; Liao et al. 2005). Lignin is considered to be insoluble (Naczk and Shahidi 2006; Pérez et al. 2002) and decomposes relatively slowly in soil contributing to stocks of recalcitrant soil organic matter especially as it becomes depolymerized and associated with mineral constituents (Angst et al. 2021). Acid insoluble ash in ADF may originate from biogenic mineral fractions and contamination from soil and dust and contain silica (Crocker et al. et al. 1998; Van Soest 1994).

Many studies have demonstrated that consumption of polyphenolic PSMs like tannins by cattle can increase $\mathrm{N}$ use efficiency, reduce enteric greenhouse gas emissions and shift the pattern of $\mathrm{N}$ excretion from urine to manure (Aboagye and Beauchemin 2019; Addisu 2016; Min et al. 2020; Orzuna-Orzuna et al. 2021; Waghorn and McNabb 2003). However, much less is known about potential effects of dietary simple PSMs, such as benzoic and cinnamic acid derivatives, on animal performance or manure quality. Manure contributions to soil fertility and organic matter are influenced by its composition, quantity, and patterns of distribution (Rayne and Aula 2020) and thus new information about the effects of simple PSMs on manure quality and quantity will be of great interest to producers seeking to benefit from combining crop and animal production (Archer et al. 2018; Sekaran et al. 2021). The direct and indirect linkages between consumption of PSMs and both animal and human health are increasingly appreciated and a focus of continuing research (Kumar and Goel 2019; SantanaMéridas et al. 2012; Tufarelli et al. 2017). Consequently there is growing consensus that an integrative approach for managing PSMs in agroecosystems is needed that will benefit humans, crops, livestock, and the soil (Clemensen et al. 2020; Iqbal et al. 2020).

While many studies have focused on the effects of dietary PSMs on animal health and productivity, fewer have addressed their effects on manure composition (Halvorson et al. 2017; Ingold et al. 2015; Powell et al. 2009) or decomposition (Hao et al. 2011; Ingold et al. 2018, 2021; Powell et al. 2011). Notably, there is dearth of information regarding interactions between nondietary PSMs and excreted manure. Manure, deposited on a field directly by animals or applied mechanically to soil, could encounter phenolic compounds, originating from plant residues or microbial activity, that might impact its composition, rate of mineralization, and subsequent nutrient availability to plants. The objective of this study was to uncover evidence of interactions between simple phenolic plant secondary compounds and excreted manure. Based in part on previous observations we hypothesized that topical applications of benzoic and cinnamic acid derivatives would increase sorption of soluble $\mathrm{N}$ in manure to the insoluble ADF fraction. Since such simple phenolic acids are common in plants and soil, they would 
likely be encountered directly by grazing animals, as part of the diet, by deposited excreta and during composting (Cascant et al. 2016; Marchiosi et al. 2020; Salami et al. 2019; Strobel 2001).

\section{Materials and methods \\ Feeding and manure collection}

The manure used in this study originated from beef cattle in the resident herd at the Northern Great Plains Research Laboratory in Mandan, ND. Samples of manure were collected from individual Angus heifers (18-months old, $385 \mathrm{~kg}$ ) after a minimum 2-week adjustment period on the diet. The heifers were fed collectively, using a feed wagon, with a mixed daily ration calculated as $9.53 \mathrm{~kg}$ oat hay, $907 \mathrm{~g}$ of corn grain and $907 \mathrm{~g}$ of dry peas ani$\mathrm{mal}^{-1} \mathrm{day}^{-1}$ (Table 1). The oat hay was locally sourced, near Almont, ND, and corn and peas were obtained from a feed mill in Harvey, ND. The ration contained 8.2\% crude protein and was intended to represent a maintenance ration for beef heifers, providing $24.3 \mathrm{Mcal} \mathrm{d}^{-1}$ allowing for $0.947 \mathrm{~kg} \mathrm{~d}^{-1}$ gain calculated using the 2016 beef cattle model (National Academies of Sciences and Medicine 2016). The average ADF content of the mixed ration (32.6\%) was comparable to other forages (Jung et al. 1997). Throughout the experiment, all animals had ad libitum access to trace mineralized salt (American Stockman Big 6) and tap water.

Manure sample collection occurred between 27 February and 13 March 2020. Cows were held individually in pens $\left(\sim 9.3 \mathrm{~m}^{2}\right)$ overnight, and manure was collected off the pen floor using a shovel the following morning. The pens had impervious concrete floors; thus, manure was easily collected with minimal contamination with urine and other substances. The pens were cleaned after each day's collection. Daily collections of manure were composited by cow, dried to a constant weight at $55{ }^{\circ} \mathrm{C}$ and ground in a Wiley mill with a $2 \mathrm{~mm}$ screen. The dry and ground samples were stored in double-bagged 1-gallon Ziplock plastic bags and frozen $\left(-20^{\circ} \mathrm{C}\right)$ until use. Representative samples of oat-hay, corn and peas used for the ration were procured and stored air-dry at room temperature until analysis.

\section{Set-up of the experimental}

We performed two separate experiments, hereafter referred to as Experiment 1 and 2 to test our hypothesis.

\section{Experiment 1}

Experiment 1 was designed as a randomized complete block. Twenty samples of manure (mass $13 \pm 0.1 \mathrm{~g}$ ) from five randomly selected heifers were weighed into $10 \mathrm{~cm}$ by $20 \mathrm{~cm}$ in-situ forage bags (ANKOM Technology, Macedon NY) and secured with two nylon zip ties. Randomly selected bags from each animal were assigned to receive one of the 20 treatment combinations (total $\mathrm{n}=100$ ), which included handling only (Untreated), deionized water $\left(\mathrm{H}_{2} \mathrm{O}\right)$ or one of the three concentrations (i.e., $0.001 \mathrm{M}, 0.01 \mathrm{M}$ or $0.1 \mathrm{M}$ ) of aqueous solutions of six compounds: sodium benzoate (B0), sodium 4-hydroxybenzoic acid (B1), 3,4-dihydroxybenzoic acid (B2), 3,4,5-trihydroxybenzoic acid monohydrate (B3, gallic acid), ammonium benzoate $(\mathrm{AB})$, and ammonium chloride (AC) (Table 2). These compounds were selected to evaluate the effects of hydroxybenzoic acids with varying substituent configurations and to determine if additions of ammonia would impact ADF-N in the presence $(\mathrm{AB})$ or absence $(\mathrm{AC})$ of a benzene ring. Derivatives of both benzoic and cinnamic acids are naturally common and sometimes added to animal feed or silage to improve stability or inhibit pathogens (Del Olmo et al. 2017; Muck et al. 2018). The treatment solutions were prepared fresh on the day of use.

Table 1 Feed analysis ${ }^{a}$ for the oat hay-corn-pea mixed ration

\begin{tabular}{|c|c|c|c|c|c|c|c|c|c|c|c|c|c|c|c|c|c|c|}
\hline & \multirow{3}{*}{$\begin{array}{l}\mathrm{CP} \\
\%\end{array}$} & \multicolumn{2}{|l|}{ Fiber } & \multirow[t]{3}{*}{ TDN } & \multirow{3}{*}{\multicolumn{2}{|c|}{$\begin{array}{l}\text { NEm NEg } \\
\text { Mcal cwt }^{-1}\end{array}$}} & \multirow{3}{*}{ Nel } & \multicolumn{6}{|c|}{ Macrominerals } & \multicolumn{5}{|c|}{ Micronutrients } \\
\hline & & \multirow[t]{2}{*}{ ADF } & \multirow[t]{2}{*}{ NDF } & & & & & \multirow{2}{*}{$\begin{array}{l}\mathrm{Ca} \\
\%\end{array}$} & \multirow[t]{2}{*}{$\mathbf{P}$} & \multirow[t]{2}{*}{ K } & \multirow[t]{2}{*}{$\mathrm{Mg}$} & \multirow[t]{2}{*}{$\mathrm{Na}$} & \multirow[t]{2}{*}{$\mathrm{S}$} & \multirow{2}{*}{$\begin{array}{l}\text { Cu } \\
\text { ppm }\end{array}$} & \multirow[t]{2}{*}{$\mathrm{Fe}$} & \multirow[t]{2}{*}{$M n$} & \multirow[t]{2}{*}{ Mo } & \multirow[t]{2}{*}{$\mathrm{Zn}$} \\
\hline & & & & & & & & & & & & & & & & & & \\
\hline \multicolumn{19}{|c|}{ Component $^{b}$} \\
\hline Oat hay & 7.0 & 36.9 & 58.3 & 60.4 & 60.1 & 34.0 & 63.2 & 0.18 & 0.10 & 1.48 & 0.14 & 0.18 & 0.12 & 2.1 & 106 & 28 & 1.65 & 43.7 \\
\hline Corn & 8.6 & 2.9 & 9.2 & 87.8 & 98.6 & 67.7 & 89.7 & 0.04 & 0.21 & 0.37 & 0.13 & 0.04 & 0.10 & 0.4 & 44 & 6 & 0.63 & 39.1 \\
\hline Peas & 19.7 & 17.0 & 23.3 & 66.2 & 68.6 & 41.7 & 86.1 & 0.22 & 0.33 & 0.91 & 0.17 & 0.05 & 0.15 & 3.9 & 129 & 13 & 0.89 & 67.0 \\
\hline Ration Mix & 8.2 & 32.6 & 51.6 & 63.0 & 63.8 & 37.3 & 67.1 & 0.17 & 0.13 & 1.35 & 0.14 & 0.16 & 0.12 & 2.1 & 103 & 25 & 1.51 & 45.2 \\
\hline
\end{tabular}

${ }^{a}$ CP: Crude Protein, (\%); ADF: Acid Detergent Fiber, (\%); NDF: Neutral Detergent Fiber, (\%); TDN: Total Digestible Nutrients, (\%); NEm: Net Energy Maint, (MCal/cwt); NEg: Net Energy Gain, (MCal/cwt); NEl: Net Energy Lact, (MCal/cwt); Ca: Calcium, (\%); P: Phosphorus, (\%); K: Potassium, (\%); Mg: Magnesium, (\%); Na: Sodium, (\%); S: Sulfur, (\%); Cu: Copper, (ppm); Fe: Iron, (ppm); Mn: Manganese, (ppm); Mo: Molybdenum, (ppm); Zn: Zinc (ppm). Dry matter values for oat hay, corn and peas were $88.6,86.8$ and $90.1 \%$ respectively. Data: from single mixed samples, are shown on a dry weight basis

${ }^{\mathrm{b}}$ Animals, fed collectively, were supplied with a total mixed ration providing $9.53 \mathrm{~kg}$ oat hay, $907 \mathrm{~g}$ of corn and $907 \mathrm{~g}$ of peas, animal ${ }^{-1}$ day $^{-1}$ 
Table 2 Some properties of the treatment compounds and 0.001 M solutions

\begin{tabular}{|c|c|c|c|c|c|c|c|}
\hline Treatment & Source & Structure & Anhydrous MW & $\mathrm{Pka}_{1}{ }^{\mathrm{a}}$ & $\mathrm{K}_{\mathrm{ow}}{ }^{\mathrm{b}}$ & $\begin{array}{l}0.001 \text { M Solution } \\
\text { Soluble-N (mg/L) }\end{array}$ & $\begin{array}{l}0.001 \mathrm{M} \\
\text { Solution }^{\mathrm{c}} \\
\mathrm{pH}\end{array}$ \\
\hline $\begin{array}{l}\text { Sodium benzoate } \\
(\mathrm{B0}, \geq 99 \%)\end{array}$ & $\begin{array}{l}\text { Alfa Aesar, Haverhill, } \\
\text { MA USA }\end{array}$ & & 144.1 & 4.2 & 1.87 & $0.08(13.0)$ & $5.33(5.22)$ \\
\hline $\begin{array}{l}\text { Sodium 4-hydroxybenzoate } \\
\text { (B1, } \geq 99 \%)\end{array}$ & $\begin{array}{l}\text { Alfa Aesar, Haverhill, } \\
\text { MA USA }\end{array}$ & & 160.1 & 4.5 & 1.58 & $0.26(14.9)$ & $5.72(5.58)$ \\
\hline $\begin{array}{l}3,4, \text { dihydroxybenzoic acid } \\
(B 2, \geq 99 \%)\end{array}$ & $\begin{array}{l}\text { Frontier Scientific, } \\
\text { Logan, UT USA }\end{array}$ & & 154.1 & 4.3 & 0.86 & $0.25(13.6)$ & $3.90(3.82)$ \\
\hline $\begin{array}{l}\text { Gallic acid monohydrate } \\
(B 3, \geq 98 \%)\end{array}$ & $\begin{array}{l}\text { Sigma-Aldrich, Inc., St } \\
\text { Louis, MO USA }\end{array}$ & & $(170)$ & 4.4 & 0.7 & $0.25(16.2)$ & $3.76(3.76)$ \\
\hline $\begin{array}{l}p \text {-Coumeric acid } \\
(p-C O U M, \geq 98 \%)\end{array}$ & $\begin{array}{l}\text { Sigma-Aldrich, Inc., St } \\
\text { Louis, MO USA }\end{array}$ & & 164.2 & 4.6 & 1.79 & $0.32(17.8)$ & $3.73(3.75)$ \\
\hline Caffeic acid $(C A F, \geq 98 \%)^{a}$ & $\begin{array}{l}\text { Sigma-Aldrich, Inc., St } \\
\text { Louis, MO USA }\end{array}$ & & 180.2 & 4.5 & 1.15 & $0.43(17.4)$ & 3.77 (3.76) \\
\hline $\begin{array}{l}\text { trans-Ferrulic acid } \\
(\mathrm{FER}, \geq 99 \%)\end{array}$ & $\begin{array}{l}\text { Sigma-Aldrich, Inc., St } \\
\text { Louis, MO., USA }\end{array}$ & & 194.2 & 4.4 & 1.51 & $0.30(16.4)$ & $3.76(3.73)$ \\
\hline $\begin{array}{l}\text { (+)-Catechin hydrate } \\
\text { (CAT, } \geq 98 \%)\end{array}$ & $\begin{array}{l}\text { Sigma-Aldrich, Inc., St } \\
\text { Louis, MO USA }\end{array}$ & & 290.3 & 8.6 & 0.51 & $0.26(16.9)$ & $7.43(6.67)$ \\
\hline $\begin{array}{l}\text { Epigallocatechin gallate } \\
\text { (EGCG, } \geq 95 \%)\end{array}$ & $\begin{array}{l}\text { Biosynth International, } \\
\text { Inc., San Diego, CA USA }\end{array}$ & & 458.4 & 7.7 & 1.2 & $0.29(15.1)$ & $6.30(5.85)$ \\
\hline
\end{tabular}

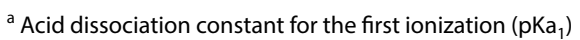

${ }^{\mathrm{b}}$ Octanol-water partition coefficients $\left(\mathrm{K}_{\text {ow }}\right)$ from https://pubchem.ncbi.nlm.nih.gov/. Low values correspond to polar compounds while higher values are indicative of nonpolar ones

${ }^{c}$ Values without parentheses are for a $0.01 \mathrm{M}$ aqueous solution of the treatment compound. Values in parentheses are for a solution containing $0.01 \mathrm{M}$ of the treatment compound + $0.01 \mathrm{M}$ Ammonium chloride 
The samples were placed into 1-quart Ziplock bags with $90 \mathrm{~mL}$ of the assigned treatment solution. Sealed Ziplock bags containing the sample and solution were agitated with an orbital shaker at $100 \mathrm{rpm}$ for $4 \mathrm{~h}$ at room temperature. After $4 \mathrm{~h}$, the excess solution was drained from the 1-quart plastic bag and the treated manure sample remaining in the in-situ bag was subjected to four vigorous rinses with deionized water alternating with firm squeezing (double-gloved hand) to remove excess liquid. After the final cycle, the washed manure sample, still contained by the Ankom in-situ bag was dried at $55{ }^{\circ} \mathrm{C}$ for a minimum of $36 \mathrm{~h}$. Dried sample bags were stored frozen $\left(-15^{\circ} \mathrm{C}\right)$ until transport for analyses.

\section{Experiment 2}

Experiment 2 was also laid out in a randomized complete block design similar to Experiment 1. However, for Experiment 2, we doubled the number of manure sources, and assessed a broader range of treatment compounds including both hydroxybenzoic and hydroxycinnamic acids, common to crops, and several other polyphenolic compounds of interest. We examined only a single solution concentration but added a second treatment factor, inorganic $\mathrm{N}$, to detect possible additive effects of the treatment compounds and additions of amino-containing compounds. We also increased the length of time that manure samples were incubated with treatment solutions, minimized subsequent sample handling, and increased post-treatment drying time.

Twenty-one samples of dried and ground manure from each of ten randomly selected heifers were prepared as described for Experiment 1. Manure samples from each animal were randomly selected to receive one of the treatment combinations, which included untreated manure, deionized water, or $0.001 \mathrm{M}$ aqueous solutions of nine compounds, namely, sodium benzoate, sodium 4-hydroxybenzoate, 3,4-dihydroxybenzoic acid, gallic acid monohydrate, $+(-)$ catechin (CAT), epigallocatechin gallate (EGCG), ferulic acid (FER), $p$-coumaric acid ( $p$-COUM), or caffeic acid (CAF) (Table 2). In addition to being a common phenolic acid, the GA treatment was of interest because it is a subcomponent of some hydrolysable tannins (e.g., 1,2,3,4,6-pentagalloylglucose) while CAT, a flavan-3-ol, was chosen because it is a building block of some condensed tannins. EGCG was included because it combines characteristics of both condensed (flavan-3-ol) and hydrolysable (galloyl group) tannins making it a useful model compound. It's low MW (relative to the usual definition for tannins) makes it easily soluble and it readily forms complexes with proteinaceous compounds (Hagerman 2012). A second set of $0.001 \mathrm{M}$ solutions was prepared that contained both the treatment compound (or $\mathrm{H}_{2} \mathrm{O}$ ) and $\mathrm{NH}_{4} \mathrm{Cl}$ added as solids at the time of each solution preparation. Thus, the total number of samples for Experiment 2 was 210 $\left(10\right.$ cows $\times 10$ treatments $\left(9\right.$ compounds $\left.+\mathrm{H}_{2} \mathrm{O}\right) \times 2 \mathrm{~N}$ treatments + Untreated).

Treatment solutions were applied to manure subsamples in Ziplock bags, sealed, and agitated for $24 \mathrm{~h}$ at room temperature. After incubation, treated manure remaining in the in-situ bags was not rinsed as in Experiment 1 but instead, excess solution was removed by manual squeezing. The damp manure sample still contained by the insitu bag was dried at $55^{\circ} \mathrm{C}$ for $72 \mathrm{~h}$. Dried sample bags were stored frozen $\left(-15^{\circ} \mathrm{C}\right)$ until transport for analyses. Aliquots of the treatment solutions were collected and stored frozen.

\section{Chemical analyses of feed and manure}

Chemical analyses were conducted on diet components and untreated manure samples by a commercial lab (Ward Laboratories Inc., Kearney, NE). Total C and $\mathrm{N}$ was determined by dry combustion using a LECO FP-2000 CN analyzer (LECO Corporation, St. Joseph, $\mathrm{MI})$. Inorganic $\mathrm{N}$ was determined colorimetrically with a Lachat Quikchem 8500 (Hach Company, Loveland, Colorado) and organic $\mathrm{N}$ estimated as the difference between total and inorganic $\mathrm{N}$. The concentrations of total $\mathrm{P}$ $\left(\mathrm{P}_{2} \mathrm{O}_{5}\right), \mathrm{K}\left(\mathrm{K}_{2} \mathrm{O}\right), \mathrm{S}, \mathrm{Ca}, \mathrm{Mg}, \mathrm{Na}, \mathrm{Zn}, \mathrm{Fe}, \mathrm{Mn}, \mathrm{Cu}$, and $\mathrm{B}$ in feed and manure were determined by Inductively Coupled Plasma (ICP) spectrometry (iCAP 6500 Duo ICP instrument, Thermo Fisher Scientific Inc., Waltham, MA) and $\mathrm{pH}$ was measured by electrode.

The effects of treatment solutions on fiber-bound $\mathrm{N}$ in manure were determined by Ward Labs from the amount of $\mathrm{N}$ (LECO) retained in acid detergent fiber (ADF-N). Acid detergent fiber was measured by the Van Soest technique (Van Soest et al. 1991) following the Ankom method (Vogel et al. 1999), using a Fiber Analyzer 220 (ANKOM Technology, Macedon, NY), and using the customary acid detergent solution.

Treatment solution $\mathrm{pH}$ was determined, and waterextractable $\mathrm{N}$ of thawed treatment solutions and untreated manure was determined using a Shimadzu TOC-LCSN analyzer equipped with a TNM-L module (Shimadzu Scientific Instruments, Columbia, MD). Samples of untreated manure $(0.3 \mathrm{~g})$, weighed into tared Oak Ridge centrifuge tubes $(50 \mathrm{~mL}$, nominal), were treated with $30 \mathrm{~mL}$ of room temperature $\left(\sim 23{ }^{\circ} \mathrm{C}\right)$ deionized water. After vortexing for $5 \mathrm{~s}$ and orbital shaking at $200 \mathrm{rpm}$ for $1 \mathrm{~h}$ at room temperature, the samples were centrifuged for $8 \mathrm{~min}$ at $10,000 \mathrm{rpm}$ $(11,952 \mathrm{~g})$, decanted through a Whatman \#1 filter paper, and the liquid was analyzed for $\mathrm{N}$ content within $5 \mathrm{~h}$. 


\section{Statistical analysis}

Data analysis for these investigations was conducted using SAS/STAT software, version 9.4 of the SAS System for Windows (๔ 2002-2012 by SAS Institute Inc., Cary, NC, USA). Average basic composition of the oat haycorn-pea diet and the manure subsequently produced by cows was determined arithmetically using PROC TABULATE.

In Experiment 1, we tested whether the ADF- $\mathrm{N}$ in manure samples was increased by the 4-h exposure to solutions of treatment compounds (one of six compounds or just $\mathrm{H}_{2} \mathrm{O}$ ) applied at three concentrations; $0.001 \mathrm{M}, 0.01 \mathrm{M}$ and $0.1 \mathrm{M}$. We performed a linear mixed effects analysis by holding the treatment compounds and concentration as fixed effects and animals $(n=5)$ to be a random effect. In Experiment 2, we tested whether the ADF-N in manure samples was increased by a 24-h exposure to a $0.001 \mathrm{M}$ solution of treatment compounds applied with or without additional inorganic $\mathrm{N}$ in the form of $\mathrm{NH}_{4} \mathrm{Cl}$. We classified the treatment compounds and added $\mathrm{N}$ as fixed effects and considered animals $(\mathrm{n}=10)$ to be a random effect.

In both experiments, the effects of treatment combinations on manure ADF-N were tested using SAS PROC GLIMMIX (Gbur et al. 2012; SAS Intitute 2013). We considered ADF-N data as binomial and fit proportions of ADF-N to the model assuming a beta distribution with a logit link. LSMEANS from fitted models were used to test effects of treatment compound, concentration, and their interaction (Experiment 1) or the effects of treatment compound, added $\mathrm{N}$, and their interaction (Experiment 2). Unless otherwise noted, post hoc multiple comparisons among treatment means were considered significant at $P \leq 0.05$ after adjustment with the TukeyKramer method. Additionally, Dunnett's test was used to compare the proportion of ADF-N for each of the treatment combinations in each experiment to the proportion of ADF-N in $\mathrm{H}_{2} \mathrm{O}$-treatment used as the "control" in Experiment 1 or untreated manure in Experiment 2, to determine whether there had been a significant change in ADF-N from initial values in the manure. The LSMEANs ( \pm standard error of the mean) produced by the mixed model analyses of ADF-N are expressed on an oven dry mass basis.

\section{Results}

\section{Experiment 1}

ADF-N demonstrated a significant $(P<0.0001)$ interaction between treatment and concentration. Main effects of treatment compound were observed at all concentrations (Fig. 1), but clear trends were not apparent across the different concentrations of each treatment. At the lowest treatment concentration $(0.001 \mathrm{M})$, average

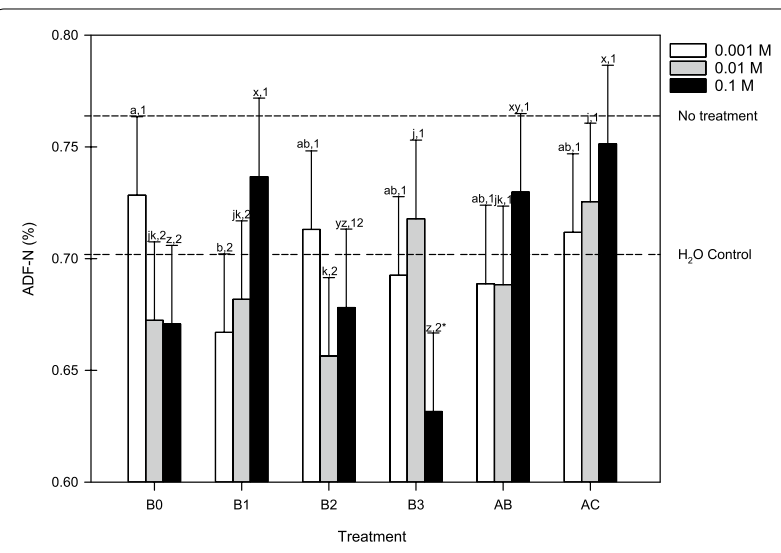

Fig. 1 Manure ADF-N (\%) for cows fed oat-hay mixed ration for Experiment 1. Bars show LSMEANS $(n=5)$, and error bars indicate the standard error calculated by the model. Abbreviations indicate sodium benzoate (BO), sodium 4-hydroxybenzoic acid (B1), 3,4-dihydroxybenzoic acid (B2), 3,4,5-trihydroxybenzoic acid monohydrate (B3, gallic acid), ammonium benzoate (AB), and ammonium chloride (AC). At each concentration, significant differences between treatments are denoted by letters. Within each treatment, significant differences between concentrations are denoted by number. Significant differences from the $\mathrm{H}_{2} \mathrm{O}$ treatment (Dunnett's $P \leq 0.05$ ) are denoted with an asterisk

ADF-N, observed in samples treated with B0, was significantly greater than the value recorded for B1. Otherwise, treatments could not be statistically distinguished from each other. The treatment with $0.01 \mathrm{M}$ solutions of $\mathrm{AC}$ and B3 resulted in the highest values of ADF-N, both significantly greater than the lowest value for B2. The difference between treatment means was more apparent at the $0.1 \mathrm{M}$ concentration. Samples treated with AC or B1 were significantly higher than samples treated with $B 0$, $\mathrm{B} 2$, or B3.

The effects of concentration also varied with treatment. Average ADF-N increased significantly together with concentration for B1. Conversely, ADF-N decreased with treatment concentration for B0, B2, and for B3. Significant effects of concentration were not observed for $\mathrm{AB}$ or $\mathrm{AC}$.

Average ADF-N in water-treated manure $(0.70 \pm 0.03 \%)$ appeared consistently less than in untreated manure $(0.76 \pm 0.03 \%)$ (Fig. 2a, Dunnett's t-test $P \leq 0.05)$ suggesting some $\mathrm{N}$ that was present in the fiber of untreated manure, was being solubilized and removed with the four vigorous rinses after each treatment period. We therefore considered values from the samples treated with $\mathrm{H}_{2} \mathrm{O}$ as a more appropriate baseline to account for any systematic errors introduced by post-treatment sample handling. Consequently, although significant effects of additions of different hydroxybenzoic acids and solution concentrations were detected by our analysis, we found little 


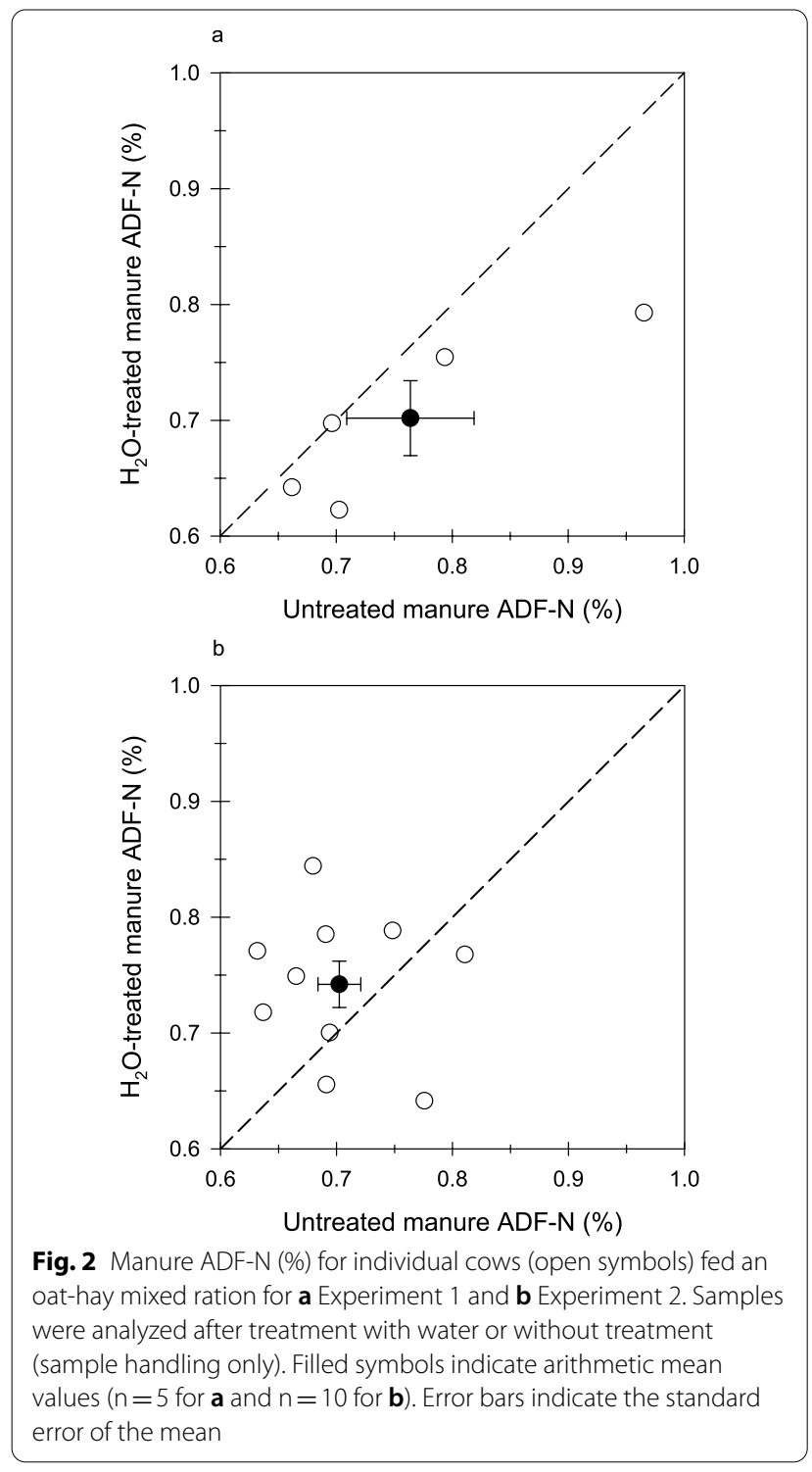

meaningful distinction between the treatment means and samples treated with water using Dunnett's test. Only the highest concentration of gallic acid resulted in significantly less ADF-N than the water control. This, together with the unexpectedly high amount of variability observed in untreated manure ADF-N among individual cows (ranging from 0.66 to $0.96 \%$ ), indicated that a more robust experiment (Experiment 2, below), employing more animals, longer exposure to treatment solutions, and less post-treatment sample handling was needed to improve detection of treatment effects.

\section{Experiment 2}

Initial manure composition, containing an average $\mathrm{C}$ and $\mathrm{N}$ of 48.1 and $2.1 \%$, respectively, demonstrated little variation among individual animals and yielded a $\mathrm{C}: \mathrm{N}$ ratio of $22.9 \pm 0.4$ (Table 3 ). Concentrations of inorganic $\mathrm{N}$ (ammonium and nitrate) were negligible compared to total $\mathrm{N}$, averaging $93 \pm 7$ and $12 \pm 1 \mathrm{mg} \mathrm{kg}^{-1}$, respectively. Manure averaged $40.2 \pm 0.9 \%$ ADF that contained an average concentration of $0.70 \pm 0.02 \% \mathrm{~N}$. Thus, $\mathrm{N}$ in the ADF fraction of manure accounted for an average $0.28 \pm 0.01 \%$ of manure dry weight or about $13 \%$ of the total $\mathrm{N}$ content of the manure.

We observed a strong main effect of treatment on ADF-N $(P<0.0001)$ but no statistically significant differences due to the added $\mathrm{NH}_{4} \mathrm{Cl}(P \geq 0.96)$ or evidence of a meaningful interaction $(\mathrm{P}>0.14)$ (Fig. 3$)$. The lowest concentrations of ADF-N were recorded in the samples treated with water, B0 and B3, but intermediate values were recorded in those treated with $\mathrm{B} 1, \mathrm{CAF}, \mathrm{B} 2$, CAT and $p$-COUM. The highest concentrations of ADF-N were observed in samples treated with EGCG and FER.

Unlike experiment 1 , average ADF-N in untreated samples $(0.70 \pm 0.02 \%)$ appeared more comparable to samples treated with water $(0.73 \pm 0.03 \%)$ (Fig. $2 b$, Dunnett's $P>0.07)$ and was therefore appropriate for use as a baseline. When compared to initial values in the untreated manure, ADF-N was not significantly affected by the $\mathrm{H}_{2} \mathrm{O}, \mathrm{B} 0$ and $\mathrm{B} 3$ treatments (Fig. 3) but was significantly increased by all other treatments. Percentage increases in ADF-N varied from 13.2 to $17.5 \%$ for the $\mathrm{B} 1, \mathrm{CAF}$ and B2 treatments, while the solutions of CAT and p-COUM increased ADF-N by 19.7 and 22.2\%, respectively. Treatment with EGCG or FER resulted in the greatest increase of ADF-N, 32.6 and $34.1 \%$, respectively. The changes in ADF-N did not appear correlated to compound properties like pKa or $\mathrm{K}_{\mathrm{ow}}$ (Table 2, Fig. 3). For example, the pKa for B0 and B3 were similar to that FER but lower than EGCG. Additionally, while the $\mathrm{K}_{\mathrm{ow}}$ for $\mathrm{B} 0$ was higher than either EGCG or FER, the $\mathrm{K}_{\mathrm{ow}}$ for B3 was lower.

\section{Discussion}

The composition of manure produced by the mixed ration (Table 3), was within the typical range of values for cattle (Van Kessel and Reeves 2002; Ward, 2018) and contained comparable concentrations of $\mathrm{N}$ as manure produced by a diet of alfalfa hay with twice as much crude protein (Halvorson et al. 2020). The concentration of manure ADF was close to values collected in a feedlot by Ward et al. (1978) of 39.7\% but lower than values for dairy cows (Pennington et al. 2009).

Although significant effects of additions of different hydroxybenzoic acids and solution concentrations were detected in Experiment 1, these results did not entirely support our hypothesis that solutions of benzoic and cinnamic acid derivatives would increase sorption of soluble $\mathrm{N}$ in manure to the insoluble ADF fraction. 
Table 3 Manure composition ${ }^{a}$ from a mixed oat hay ration ${ }^{b}$

\begin{tabular}{|c|c|c|c|c|c|c|c|c|c|c|c|c|c|c|c|c|c|c|}
\hline Cow & $\mathrm{pH}_{\mathrm{w}}$ & $\begin{array}{l}c_{\text {tot }} \\
\%\end{array}$ & $\mathrm{~N}_{\text {tot }}$ & $\mathrm{N}_{\mathrm{H} 2 \mathrm{O}}$ & ADF & ADF-N & $\mathrm{N}_{\text {adf }}$ & $\mathrm{P}_{2} \mathrm{O}_{5}$ & $\mathrm{~K}_{2} \mathrm{O}$ & $S$ & $\mathrm{Ca}$ & $\mathrm{Mg}$ & $\mathrm{Na}$ & $\begin{array}{l}\mathrm{Zn} \\
\mathrm{mg} \mathrm{kg}\end{array}$ & $\mathrm{Fe}$ & $\mathrm{Mn}$ & $\mathrm{Cu}$ & B \\
\hline 1 & 8.4 & 48.7 & 2.12 & 0.52 & 38.7 & 0.69 & 0.27 & 0.88 & 1.93 & 0.26 & 0.46 & 0.41 & 0.51 & 89.8 & 812.3 & 92.3 & 13.29 & 9.89 \\
\hline 2 & 8.6 & 47.8 & 1.93 & 0.40 & 42.2 & 0.63 & 0.27 & 0.98 & 2.37 & 0.24 & 0.46 & 0.33 & 0.57 & 96.8 & 611.3 & 84.6 & 13.29 & 8.79 \\
\hline 3 & 9.0 & 46.4 & 2.16 & 0.44 & 40.1 & 0.75 & 0.30 & 0.81 & 2.88 & 0.32 & 0.45 & 0.44 & 0.78 & 91.6 & 1178.2 & 107.6 & 14.50 & 12.31 \\
\hline 4 & 6.1 & 48.6 & 2.24 & 0.36 & 33.0 & 0.78 & 0.26 & 1.18 & 1.33 & 0.23 & 0.47 & 0.45 & 0.21 & 90.0 & 515.1 & 89.9 & 13.73 & 7.14 \\
\hline 5 & 7.8 & 48.7 & 2.13 & 0.44 & 39.4 & 0.69 & 0.27 & 0.75 & 1.29 & 0.24 & 0.51 & 0.41 & 0.37 & 69.7 & 906.4 & 105.5 & 12.64 & 8.79 \\
\hline 6 & 8.1 & 49.1 & 2.04 & 0.43 & 41.9 & 0.68 & 0.29 & 0.58 & 0.88 & 0.22 & 0.39 & 0.37 & 0.51 & 142.2 & 706.0 & 119.1 & 16.70 & 7.69 \\
\hline 7 & 8.3 & 47.4 & 2.08 & 0.52 & 39.9 & 0.69 & 0.28 & 0.91 & 1.65 & 0.26 & 0.40 & 0.42 & 0.78 & 113.8 & 715.5 & 103.2 & 14.94 & 10.22 \\
\hline 8 & 8.3 & 48.9 & 2.10 & 0.53 & 41.9 & 0.67 & 0.28 & 0.80 & 1.47 & 0.24 & 0.48 & 0.41 & 0.46 & 67.4 & 476.6 & 88.7 & 12.53 & 8.90 \\
\hline 9 & 8.8 & 46.4 & 2.26 & 0.56 & 41.5 & 0.81 & 0.34 & 0.55 & 1.82 & 0.23 & 0.39 & 0.33 & 0.45 & 82.0 & 1693.1 & 100.1 & 11.21 & 9.45 \\
\hline 10 & 7.8 & 48.8 & 1.98 & 0.46 & 43.4 & 0.64 & 0.28 & 0.69 & 1.35 & 0.20 & 0.35 & 0.32 & 0.15 & 71.1 & 347.6 & 73.2 & 10.22 & 6.92 \\
\hline Avg. & 8.1 & 48.08 & 2.11 & 0.47 & 40.2 & 0.70 & 0.28 & 0.81 & 1.70 & 0.25 & 0.44 & 0.39 & 0.48 & 91.4 & 796.2 & 96.4 & 13.3 & 9.00 \\
\hline SEM & 0.3 & 0.3 & 0.03 & 0.02 & 0.9 & 0.02 & 0.01 & 0.06 & 0.18 & 0.01 & 0.02 & 0.02 & 0.07 & 7.2 & 124.5 & 4.2 & 0.6 & 0.51 \\
\hline CV\% & 10.0 & 2.1 & 5.0 & 13.6 & 7.3 & 8.3 & 8.1 & 23.0 & 34.4 & 13.2 & 11.9 & 12.2 & 43.0 & 24.9 & 49.3 & 13.7 & 13.9 & 17.7 \\
\hline
\end{tabular}

${ }^{a}$ pHw: manure $\mathrm{pH}$ determined with $\mathrm{H}_{2} \mathrm{O} ; \mathrm{C}_{\text {tot }}$ : Total $\mathrm{C},(\%) ; \mathrm{N}_{\text {tot }}$ : Total $\mathrm{N},(\%)$; $\mathrm{N}_{\mathrm{H}_{2} \mathrm{O}}$ : Water-extractable N (\%); ADF: Acid detergent fiber (\%); ADF-N: the concentration of nitrogen in ADF (\%); $\mathrm{N}_{\text {adf: }}$ the product of ADF and ADF-N (\%); $\mathrm{P}_{2} \mathrm{O}_{5}$ : Phosphorus, $\left(\% \mathrm{P}_{2} \mathrm{O}_{5}\right)$; $\mathrm{K}_{2} \mathrm{O}$ : Potassium, $\left(\% \mathrm{~K}_{2} \mathrm{O}\right)$; $\mathrm{S}$ : Sulfur, (\%); Ca: Calcium, (\%); Mg: Magnesium, (\%); Na: Sodium, (\%); Zn: Zinc (ppm); Fe: Iron, (ppm); Mn: Manganese, (ppm); Cu: Copper, (ppm); B: Boron, (ppm). Values are corrected to a dry weight basis for manure dried at $55^{\circ} \mathrm{C}$ for $72 \mathrm{~h}$ ( $9 \%$ moisture content). Mean and standard errors (SEM) are arithmetic

${ }^{b}$ Animals $(n=10)$, fed collectively, were supplied with a mixed daily ration composed of $9.53 \mathrm{~kg}$ oat hay, $907 \mathrm{~g}$ of corn, and $907 \mathrm{~g}$ of peas, animal ${ }^{-1}$ day ${ }^{-1}$

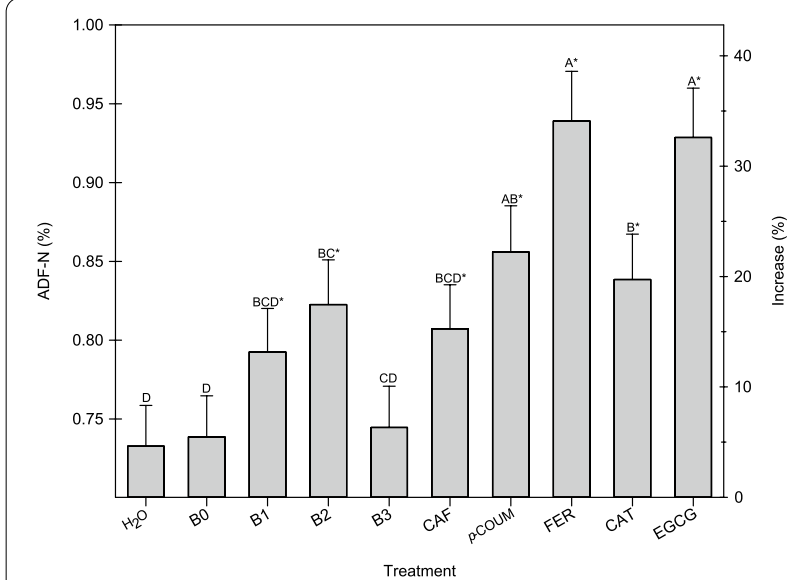

Fig. 3 Manure ADF-N (\%) for cows fed oat-hay mixed ration for Experiment 2. Bars show LSMEANS $(n=10)$, and error bars indicate the standard error calculated by the model. Abbreviations indicate water $\left(\mathrm{H}_{2} \mathrm{O}\right)$, sodium benzoate (BO), sodium 4-hydroxybenzoic acid (B1), 3,4-dihydroxybenzoic acid (B2), 3,4,5-trihydroxybenzoic acid monohydrate (B3, gallic acid), caffeic acid (CAF), p-coumaric acid ( $p$-COUM), ferulic acid (FER), + $(-)$ catechin (CAT),

and epigallocatechin gallate (EGCG). Significant differences between treatments are denoted by letters. Significant differences from untreated manure (Dunnett's $P \leq 0.05$ ) are denoted with an asterisk

Unexpectedly, the results revealed considerable variability in the concentration of manure ADF-N, even among animals fed the same ration. However, they also indicated manure ADF-N could be readily affected by some of the treatments.
The treatment effects on manure ADF-N observed were complex, and influenced by treatment compound, and concentration. The oat-hay ration resulted in manure in which ADF-N concentration was negatively related to the number of functional groups on hydroxybenzoic acids (compare B1-B3 in Fig. 1), but this pattern was observed only at the highest treatment concentration. At the lower concentrations, the relationship between ADF-N and $\mathrm{OH}$ functional groups did not show clear trends. Losses of some $\mathrm{N}$ from ADF with post treatment sample-handling suggests that it was not covalently held on the fiber but more likely linked by easily disrupted electrostatic interactions, hydrogen bonds or hydrophobic forces.

In Experiment 2, concentrations of ADF-N were significantly increased by all treatments except B0 and B3 indicating that most of the compounds immobilized some organic $\mathrm{N}$ species on manure fibers or perhaps acid insoluble ash. The lack of statistically significant change due to additions of ammonium chloride was somewhat surprising but in retrospect, the amount of $\mathrm{N}$ added to manure samples as $\mathrm{NH}_{4} \mathrm{Cl}$ was very small (about $100 \mathrm{mg} \mathrm{kg}^{-1}$ manure) compared to the relatively high concentration of $\mathrm{N}$ already present in the manure $(2.11 \%$, Table 3$)$ and probably unlikely to be detected.

Mechanisms responsible for increased ADF-N due to solutions of phenolic compounds need further elucidation. No simple relationships were apparent between changes in ADF-N and compound $\mathrm{pKa}$ or $\mathrm{K}_{\mathrm{ow}}$ suggesting that $\mathrm{N}$ in manure does not form complexes with manure ADF by simple electrostatic or hydrophobic interactions. 
We speculate that our observations might reasonably involve potential redox or binding effects associated with phenolic chemistry. Possible mechanisms could include ligand exchange, Coulombic forces, van der Waals forces, hydrophobic forces, hydrogen bonding, cation bridging, and chelation (Gmach et al. 2019; Philippe and Schaumann 2014). Complexation and retention of dissolved organic matter is likely to be favored by the formation of bidentate complexes between two organic ligands in ortho position of an aromatic ring and a $2+$ charge metal such as magnesium and calcium at the surface of oxides and hydroxides. Both are found lignocellulose-derived hydrophobic fractions and a feature of manure (Kaiser and Guggenberger 2000; Table 3; Philippe and Schaumann 2014; Slabbert 1992).

Sorption of organic N by ADF constituents, observed in experiment 2 , could have been partially induced by the relatively low $\mathrm{pH}$ of some of the treatment solutions and their effects on the degree of ionization of soluble amino-containing compounds in manure. Organic $\mathrm{N}$ accounted for the vast majority of the total $\mathrm{N}$ in manure and contains many amino-containing compounds (de Moura Zanine and de Jesus Ferreira 2015). The relatively low $\mathrm{pH}(<4)$ of B2, B3 $p$-COUM, CAF and FER treatment solutions could favor a protonated state for some amino groups on organic $\mathrm{N}$ and facilitate their sorption on the negatively charged sites. The surface charge of cellulose and lignin would be expected to be negative in an aqueous medium due to their characteristic carboxyl and hydroxyl groups (Ribitsch et al. 1996). However, the impact of a low treatment solution $\mathrm{pH}$ needed to induce a protonated state for amino acids may have been nullified by the $\mathrm{pH}$ of the manure that averaged 8.1 (Table 3). Further, solution $\mathrm{pH}$ cannot be invoked to explain the significant increases in ADF-N observed for the B1 and CAT or EGCG, treatments with relatively high solution $\mathrm{pH}$. Of those only EGCG, a tannin, would be expected to form complexes with proteins or other nitrogenous compounds (Adamczyk et al. 2011; Hagerman 2012) that might sorb to ADF.

Experiment 2 supports a hypothesis that organic $\mathrm{N}$ in excreted manure can complex with the cellulose, lignin or ash that comprises ADF upon exposure to benzoic and especially cinnamic acid derivatives. However, the exact nature of these complexes will be influenced by the concentration and composition of nitrogen in the manure and the phenolic compounds themselves, the reaction conditions such as temperature or $\mathrm{pH}$, and characteristics of the ADF that might vary with diet or with the individual animal. Similarly, crop residues or organic matter may interact directly with simple phenolic compounds in the soil and undergo reactions that could influence nutrient cycling. Mineralization kinetics of manure nutrients may be impacted by increasing or decreasing the amount of $\mathrm{N}$ bound to manure fibers. Therefore, we recommend further studies to learn if such complexed $\mathrm{N}$ is, at least temporarily, sequestered and thus less available to plants, for microbial mineralization, volatilization or leaching.

\section{Acknowledgements}

The authors thank the following people for their excellent technical assistance with various aspects of this study: John Mortensen, Clay Erickson, Rebecca Knutson, and Nicole Hanson. Also, we thank Ray Ward and the technical associates of Ward Laboratories, especially Rebecca Kern, for analytical assistance. The U.S. Department of Agriculture (USDA) prohibits discrimination in all its programs and activities based on race, color, national origin, age, disability, and where applicable, sex, marital status, family status, parental status, religion, sexual orientation, genetic information, political beliefs, reprisal, or because all or part of an individual's income is derived from any public assistance program. (Not all prohibited bases apply to all programs.). USDA is an equal opportunity provider and employer. Mention of commercial products and organizations in this manuscript is solely to provide specific information. It does not constitute endorsement by USDA-ARS over other products and organizations not mentioned.

\section{Authors' contributions}

JJH initiated and conducted the experiment, analyzed the data, and took the lead on drafting the manuscript. SLK made substantial contributions to animal care, acquisition and handling of manure samples, and interpretation of the data. RGC provided expertise and analysis of phenolic compound effects on ruminant physiology and contributed to manuscript architecture. AEH provided key contributions to experimental conceptualization and design and interpretation of phenolic acid chemistry. DWA provided overall project leadership, logistical support, and interpretation of agroecosystem implications of the data. All authors made substantive contributions to initial drafts, subsequently revised later versions of the manuscript, and approved the submitted version. All authors read and approved the final manuscript.

\section{Funding}

Funding for this research originated from the United States Department of Agriculture-Agricultural Research Service.

\section{Availability of data and materials}

The datasets during and/or analyzed during the current study available from the corresponding author on reasonable request.

\section{Declarations}

Ethics approval and consent to participate

Manure used in this study originated from beef cattle in the resident herd at the Northern Great Plains Research Laboratory in Mandan, ND. The protocols for animal care and procurement of manure were approved by the animal care and use committee of the Northern Great Plains Research Laboratory in Mandan, North Dakota following procedures for management of livestock being bred, conditioned or held at the Northern Great Plains Research Laboratory but not used in research. Standards in the Federation of Animal Science Societies' Guide (3rd edition) for the Care and Use of Agricultural Animals in Research and Teaching were followed.

\section{Consent for publication \\ Not Applicable.}

\section{Competing interests}

The authors declare that they have no competing interests.

\section{Author details}

${ }^{1}$ USDA Agricultural Research Service, Northern Great Plains Research Laboratory, Mandan, ND 58554, USA. ${ }^{2}$ Dept. of Chemistry and Biochemistry, Miami University, Oxford, OH 45056, USA. 
Received: 14 October 2021 Accepted: 24 January 2022

Published online: 22 February 2022

\section{References}

Aboagye IA, Beauchemin KA. Potential of molecular weight and structure of tannins to reduce methane emissions from ruminants: a review. Animals. 2019;9:856.

Adamczyk B, Adamczyk S, Smolander A, Kitunen V. Tannic acid and Norway spruce condensed tannins can precipitate various organic nitrogen compounds. Soil Biol Biochem. 2011;43:628-37. https://doi.org/10.1016/j. soilbio.2010.11.034

Addisu S. Effect of dietary tannin source feeds on ruminal fermentation and production of cattle; a review. Online J Anim Feed Res. 2016:6:45-56.

Angst G, Mueller KE, Nierop KGJ, Simpson MJ. Plant- or microbial-derived? A review on the molecular composition of stabilized soil organic matter. Soil Biol Biochem. 2021;156: 108189. https://doi.org/10.1016/j.soilbio. 2021.108189

Archer DW, Franco JG, Halvorson JJ, Pokharel KP. Integrated farming systems. Encycl Ecol. 2018;4:508-14.

Cascant M, Sisouane M, Tahiri S, Krati ME, Cervera M, Garrigues S, De la Guardia M. Determination of total phenolic compounds in compost by infrared spectroscopy. Talanta. 2016:153:360-5.

Cecchi AM, Koskinen WC, Cheng H, Haider K. Sorption-desorption of phenolic acids as affected by soil properties. Biol Fertil Soils. 2004;39:235-42.

Chomel M, Guittonny-Larchevêque M, Fernandez C, Gallet C, DesRochers A, Pare D, Jackson BG, Baldy V. Plant secondary metabolites: a key driver of litter decomposition and soil nutrient cycling. J Ecol. 2016;104:1527-41.

Clemensen AK, Provenza FD, Hendrickson JR, Grusak MA. Ecological implications of plant secondary metabolites-phytochemical diversity can enhance agricultural sustainability. Front Sustain Food Syst. 2020;4:233.

Colburn MW, Evans JL. Chemical composition of the cell-wall constituen and acid detergent fiber fractions of forages. J Dairy Sci. 1967;50:1130-5. https://doi.org/10.3168/jds.S0022-0302(67)87578-7.

Crocker LM, Depeters EJ, Fadel JG, Essex SE, Perez-Monti H, Taylor SJ. Ash content of detergent fibers in feeds, digesta, and feces and its relevance in fiber digestibility calculations. J Dairy Sci. 1998;81:1010-4. https://doi. org/10.3168/jds.S0022-0302(98)75662-0.

de Moura Zanine A, de Jesus FD. Animal manure as a nitrogen source to grass. Am J Plant Sci. 2015;6:899.

Del Olmo A, Calzada J, Nuñez M. Benzoic acid and its derivatives as naturally occurring compounds in foods and as additives: uses, exposure, and controversy. Crit Rev Food Sci Nutr. 2017;57:3084-103.

Espinosa E, Sánchez R, Otero R, Domínguez-Robles J, Rodríguez A. A comparative study of the suitability of different cereal straws for lignocellulose nanofibers isolation. Int J Biol Macromol. 2017;103:990-9. https://doi.org/ 10.1016/j.ijbiomac.2017.05.156.

Gbur EE, Stroup WW, McCarter KS, Durham S, Young LJ, Christman M, West M, Kramer M (2012) More complex examples. Analysis of Generalized Linear Mixed Models in the Agricultural and Natural Resources Sciences:199-236.

Gmach MR, Cherubin MR, Kaiser K, Cerri CEP. Processes that influence dissolved organic matter in the soil: a review. Scientia Agricola. 2019;77

Gunia-Krzyżak A, Słoczyńska K, Popiół J, Koczurkiewicz P, Marona H, Pękala E. Cinnamic acid derivatives in cosmetics: current use and future prospects. Int J Cosmet Sci. 2018:40:356-66.

Hagerman AE, et al. Fifty years of polyphenol-protein complexes. In: Cheyneir $\checkmark$, et al., editors. Recent advances in polyphenol research. Wiley-Blackwell: Hoboken; 2012. p. 71-91.

Halvorson JJ, Gonzalez JM, Hagerman AE. Retention of tannin-C is associated with decreased soluble nitrogen and increased cation exchange capacity in a broad range of soils. Soil Sci Soc Am J. 2013;77:1199-213. https://doi. org/10.2136/sssaj2012.0326.

Halvorson JJ, Schmidt MA, Hagerman AE, Gonzalez JM, Liebig MA. Reduction of soluble nitrogen and mobilization of plant nutrients in soils from U.S northern Great Plains agroecosystems by phenolic compounds. Soil Biol Biochem. 2016:94:211-21. https://doi.org/10.1016/j.soilbio.2015.11.022.

Halvorson J, Kronberg S, Hagerman A. Effects of dietary tannins on total and extractable nutrients from manure. J Anim Sci. 2017:95:3654-65.
Halvorson JJ, Kronberg SL, Christensen RG, Hagerman AE, Archer DW (2020) Nitrogen Bound to Manure Fiber Is Affected By Applications of Benzoic Acid and Its Simple Derivatives [Abstract]. ASA, CSSA and SSSA International Annual Meetings (2020) |VIRTUAL, Phoenix, AZ. https://scisoc. confex.com/scisoc/2020am/meetingapp.cgi/Paper/125158

Hao X, Benke MB, Li C, Larney FJ, Beauchemin KA, McAllister TA. Nitrogen transformations and greenhouse gas emissions during composting of manure from cattle fed diets containing corn dried distillers grains with solubles and condensed tannins. Anim Feed Sci Technol. 2011;166:539-49.

Hättenschwiler S, Vitousek PM. The role of polyphenols in terrestrial ecosystem nutrient cycling. Trends Ecol Evol. 2000;15:238-43.

Ingold M, Al-Kindi A, Jordan G, Dietz H, Schlecht E, Buerkert A. Effects of activated charcoal and Quebracho tannins added to feed or as soil conditioner on manure quality in organic agriculture. Org Agric. 2015;5:245-61.

Ingold M, Schmidt S, Dietz H, Joergensen RG, Schlecht E, Buerkert A. Tannins in goat diets modify manure turnover in a subtropical soil. Exp Agric. 2018;54:655-69.

Ingold M, Wachendorf C, Buerkert A. Net-mineralization of organic matter and greenhouse gas emissions from Quebracho tannin-enriched manure applied to acidic and alkaline soils. J Plant Nutr Soil Sci. 2021;184:530-42.

Intitute SAS. Base SAS 9.4 procedures guide: statistical procedures. Cary: SAS Institute Inc; 2013.

lqbal A, Hamayun M, Shah F, Hussain A. Role of plant bioactives in sustainable agriculture, environment, climate, plant and vegetation growth. Berlin: Springer; 2020. p. 591-605.

Jung $H G$, Mertens DR, Payne AJ. Correlation of acid detergent lignin and Klason lignin with digestibility of forage dry matter and neutral detergent fiber. J Dairy Sci. 1997;80:1622-8. https://doi.org/10.3168/jds.S0022 0302(97)76093-4.

Kaiser K, Guggenberger G. The role of DOM sorption to mineral surfaces in the preservation of organic matter in soils. Org Geochem. 2000;31:711-25. https://doi.org/10.1016/S0146-6380(00)00046-2.

Kelln B, Penner GB, Acharya SN, McAllister TA, Lardner HA. Impact of condensed tannin-containing legumes on ruminal fermentation, nutrition, and performance in ruminants: a review. Can J Anim Sci. 2020:101:210-23.

Kim D. Physico-chemical conversion of lignocellulose: inhibitor effects and detoxification strategies: a mini review. Molecules. 2018;23:309.

Kong C-H, Xuan TD, Khanh TD, Tran H-D, Trung NT. Allelochemicals and signaling chemicals in plants. Molecules. 2019;24:2737.

Kumar N, Goel N. Phenolic acids: natural versatile molecules with promising therapeutic applications. Biotechnol Rep. 2019;24: e00370. https://doi. org/10.1016/j.btre.2019.e00370.

Kumar S, Abedin MM, Singh AK, Das S. Role of phenolic compounds in plantdefensive mechanisms, plant phenolics in sustainable agriculture. Berlin: Springer; 2020. p. 517-32.

Ku-Vera JC, Jiménez-Ocampo R, Valencia-Salazar SS, Montoya-Flores MD, Molina-Botero IC, Arango J, Gómez-Bravo CA, Aguilar-Pérez CF, SolorioSánchez FJ. Role of secondary plant metabolites on enteric methane mitigation in ruminants. Front Vet Sci. 2020;7:584.

Liao W, Wen Z, Hurley S, Liu Y, Liu C, Chen S. Effects of hemicellulose and lignin on enzymatic hydrolysis of cellulose from dairy manure, Twenty-Sixth Symposium on Biotechnology for Fuels and Chemicals. Berlin: Springer; 2005. p. 1017-30

Licitra G, Hernandez T, Van Soest P. Standardization of procedures for nitrogen fractionation of ruminant feeds. Anim Feed Sci Technol. 1996;57:347-58.

Makino T, Takahashi Y, Sakurai Y, Nanzyo M. Influence of soil chemical properties on adsorption and oxidation of phenolic acids in soil suspension. Soil Sci Plant Nutr. 1996:42:867-79. https://doi.org/10.1080/00380768.1996. 10416634.

Mallik A. Effect of phenolic compounds on selected soil properties. For Ecol Manage. 1997:92:11-8.

Mandal SM, Chakraborty D, Dey S. Phenolic acids act as signaling molecules in plant-microbe symbioses. Plant Signal Behav. 2010;5:359-68.

Marchiosi R, dos Santos WD, Constantin RP, de Lima RB, Soares AR, Finger-Teixeira A, Mota TR, de Oliveira DM, Foletto-Felipe MP, Abrahao J. Biosynthesis and metabolic actions of simple phenolic acids in plants. Phytochem Rev. 2020;19:865-906.

Maxin G, Graulet B, Le Morvan A, Picard F, Portelli J, Andueza D. Cover crops as alternative forages for ruminants: nutritive characteristics, in vitro 
digestibility, methane and ammonia production. Anim Prod Sci. 2020;60:823-32.

McGivern BB, Tfaily MM, Borton MA, Kosina SM, Daly RA, Nicora CD, Purvine SO, Wong AR, Lipton MS, Hoyt DW. Decrypting bacterial polyphenol metabolism in an anoxic wetland soil. Nat Commun. 2021;12:1-16.

Min BR, Solaiman S, Waldrip HM, Parker D, Todd RW, Brauer D. Dietary mitigation of enteric methane emissions from ruminants: a review of plant tannins mitigation options hr. Anim Nutr. 2020;6(3):231-46.

Muck R, Nadeau E, McAllister T, Contreras-Govea F, Santos M, Kung L Jr. Silage review: recent advances and future uses of silage additives. J Dairy Sci. 2018;101:3980-4000.

Naczk M, Shahidi F. Phenolics in cereals, fruits and vegetables: occurrence, extraction and analysis. J Pharm Biomed Anal. 2006:41:1523-42.

Naikoo MI, Dar MI, Raghib F, Jaleel H, Ahmad B, Raina A, Khan FA, Naushin F (2019) Role and regulation of plants phenolics in abiotic stress tolerance: an overview. Plant signaling molecules.157-168.

National Academies of Sciences Engineering, Medicine. Nutrient requirements of beef cattle: eighth revised editions. Washington: The National Academies Press; 2016.

Orzuna-Orzuna JF, Dorantes-Iturbide G, Lara-Bueno A, Mendoza-Martínez GD, Miranda-Romero LA, Hernández-García PA. Effects of dietary tannins' supplementation on growth performance, rumen fermentation, and enteric methane emissions in beef cattle: a meta-analysis. Sustainability. 2021;13:7410

Otte BA, Rice CP, Davis BW, Schomberg HH, Mirsky SB, Tully KL. Phenolic acids released to soil during cereal rye cover crop decomposition. Chemoecology. 2020;30:25-34.

Pennington JA, VanDevender K, Jennings JA (2009) Nutrient and fertilizer value of dairy manure.

Pérez J, Munoz-Dorado J, De la Rubia T, Martinez J. Biodegradation and biological treatments of cellulose, hemicellulose and lignin: an overview. Int Microbiol. 2002;5:53-63.

Philippe A, Schaumann GE. Interactions of dissolved organic matter with natural and engineered inorganic colloids: a review. Environ Sci Technol. 2014:48:8946-62. https://doi.org/10.1021/es502342r.

Powell J, Broderick G, Grabber J, Hymes-Fecht U. Effects of forage proteinbinding polyphenols on chemistry of dairy excreta. J Dairy Sci. 2009;92:1765-9.

Powell JM, Aguerre MJ, Wattiaux MA. Dietary crude protein and tannin impact dairy manure chemistry and ammonia emissions from incubated soils. $J$ Environ Qual. 2011;40:1767-74. https://doi.org/10.2134/jeq2011.0085.

Rayne N, Aula L. Livestock manure and the impacts on soil health: a review. Soil Syst. 2020;4:64.

Ribitsch V, Stana-Kleinschek K, Jeler S. The influence of classical and enzymatic treatment on the surface charge of cellulose fibres. Colloid Polym Sci. 1996;274:388-94. https://doi.org/10.1007/BF00654060.

Salami SA, Luciano G, O'Grady MN, Biondi L, Newbold CJ, Kerry JP, Priolo A. Sustainability of feeding plant by-products: a review of the implications for ruminant meat production. Anim Feed Sci Technol. 2019;251:37-55. https://doi.org/10.1016/j.anifeedsci.2019.02.006.

Santana-Méridas O, González-Coloma A, Sánchez-Vioque R. Agricultural residues as a source of bioactive natural products. Phytochem Rev. 2012:11:447-66.

Schmidt MA, Kreinberg AJ, Gonzalez JM, Halvorson JJ, French E, Bollmann A, Hagerman AE. Soil microbial communities respond differently to three chemically defined polyphenols. Plant Physiol Biochem. 2013;72:190-7. https://doi.org/10.1016/j.plaphy.2013.03.003.

Sekaran U, Lai L, Ussiri DA, Kumar S, Clay S. Role of integrated crop-livestock systems in improving agriculture production and addressing food security—a review. J Agric Food Res. 2021;5:100190.

Siqueira JO, Nair MG, Hammerschmidt R, Safir GR, Putnam AR. Significance of phenolic compounds in plant-soil-microbial systems. Crit Rev Plant Sci. 1991;10:63-121. https://doi.org/10.1080/07352689109382307.

Slabbert N. Complexation of condensed tannins with metal ions, plant polyphenols. Berlin: Springer; 1992. p. 421-36.

Šmejkalová D, Piccolo A, Spiteller M. Oligomerization of humic phenolic monomers by oxidative coupling under biomimetic catalysis. Environ Sci Technol. 2006:40:6955-62.

Sokol NW, Sanderman J, Bradford MA. Pathways of mineral-associated soil organic matter formation: Integrating the role of plant carbon source, chemistry, and point of entry. Glob Change Biol. 2019;25:12-24.
Strobel BW. Influence of vegetation on low-molecular-weight carboxylic acids in soil solution—a review. Geoderma. 2001;99:169-98. https://doi.org/10. 1016/S0016-7061(00)00102-6.

Stuper-Szablewska K, Perkowski J. Phenolic acids in cereal grain: occurrence, biosynthesis, metabolism and role in living organisms. Crit Rev Food Sc Nutr. 2019;59:664-75. https://doi.org/10.1080/10408398.2017.1387096.

Tufarelli V, Casalino E, D'Alessandro AG, Laudadio V. Dietary phenolic compounds: biochemistry, metabolism and significance in animal and human health. Curr Drug Metab. 2017;18:905-13.

Van Soest PJ. Nutritional ecology of the ruminant. 2nd ed. New York: Cornell University Press; 1994.

Van Kessel J, Reeves J. Nitrogen mineralization potential of dairy manures and its relationship to composition. Biol Fertil Soils. 2002;36:118-23. https:// doi.org/10.1007/s00374-002-0516-y.

Van Soest PJ, Robertson JB, Lewis BA. Methods for dietary fiber, neutral detergent fiber, and nonstarch polysaccharides in relation to animal nutrition. J Dairy Sci. 1991;74:3583-97.

Vogel KP, Pedersen JF, Masterson SD, Toy JJ. Evaluation of a filter bag system for NDF, ADF, and IVDMD forage analysis. Crop Sci. 1999;39:276-9. https:// doi.org/10.2135/cropsci1999.0011183X003900010042x.

Waghorn GC, McNabb WC. Consequences of plant phenolic compounds for productivity and health of ruminants. Proc Nutr Soc. 2003;62:383-92.

Ward G., Muscato T., Hill D., Hansen R. (1978) Chemical composition of feedlot manure, Wiley Online Library.

Ward R. (2018) Unpublished Manure Analysis for 2013-2017, Ward Labs.

Yang L, Wen K-S, Ruan X, Zhao Y-X, Wei F, Wang Q. Response of plant secondary metabolites to environmental factors. Molecules. 2018;23:762.

\section{Publisher's Note}

Springer Nature remains neutral with regard to jurisdictional claims in published maps and institutional affiliations.

Ready to submit your research? Choose BMC and benefit from:

- fast, convenient online submission

- thorough peer review by experienced researchers in your field

- rapid publication on acceptance

- support for research data, including large and complex data types

- gold Open Access which fosters wider collaboration and increased citations

- maximum visibility for your research: over 100M website views per year

At BMC, research is always in progress.

Learn more biomedcentral.com/submissions 